\title{
THE EFFECT OF CAUSALITY ON SOLVING CRIMINAL LAW ISSUES
}

\section{Volodymyr Benkivsky}

\section{INTRODUCTION}

The issue of causation and causation in the criminal law of Ukraine and other countries is quite urgent.

The importance of the study of causation in modern criminal law is confirmed by its legal interpretations both within the Criminal Code of Ukraine $^{1}$ and within the codified acts of other countries. In particular, it is possible to note the previous editions of the Criminal Code of Moldova, the current version of the Criminal Code of Georgia ${ }^{2}$, the Model Criminal Code of the USA. With regard to the Criminal Code of Ukraine, the modeling of causality in the Criminal Code is a promising and possible way (tool) for accurate resolution of issues of criminal law evaluation.

Problems in criminal law were investigated in the scientific works of such scientists as M. Bury, I. Crees, A. Feuerbach, F. List, N.S. Tagantsev, V.I. Kofman, M.I. Kovalev, T.V. Tsereteli, A.A. Piontkovsky, T.L. Sergeeva, V.M. Kudryavtsev, M. Brainin, M.D. Shargorodsky, A.V. Uspensky, P. Leyland, V.B. Malinin, E.V. Fesenko, A.A. Muzyka, S.O. Efremov, S.R. Bagirov, O.L. Tymchuk and others.

In part, as part of the study of the differentiation of liability for negligent crimes, issues other than causal deterministic dependence were considered in the collective paper A.A. Muzyky and S.R. Bagirov's "Causal Connection: Criminal Law Outline" (2009).

However, at the dissertation and monograph level, only some criminal issues of causality were investigated; as a rule, the problem of causality in the context of modern criminal justice research was considered rather schematically.

In particular, scientists point out the difference between functional and causal relationships; temporal connections from causal; causal relationship relationships and more.

${ }^{1}$ Tatsiy V.Ya., Pshonka V.P., Borisova V.I., Tutyugina V.I. (eds.) (2013) Kryminaljnyj kodeks Ukrajiny: Naukovo-praktychnyj komentar. 2 t. [Criminal Code of Ukraine: Scientific and Pracrical Commentary, vol. 2]. Kyiv, p. 1040.

${ }^{2}$ Bigvava Z.K. (2002) Ugolovnyy kodeks Respubliki Gruzii [The Criminal Code of Georgia]. St. Petersburg: Law Center Press, p. 409. 
At the same time, there was almost no required institutional analysis within the framework of criminal law institutions.

The purpose of this study is to conceptually characterize the theory and legislative reflection of causation in criminal law. Within the framework of this study, it is necessary to pay attention to specifying the scientific provisions of the research topic; in particular, it is important to study the various aspects of the formation of modern approaches to the study of causation within Ukraine ${ }^{3}$ and abroad.

\section{Theoretical aspect of causation analysis in criminal law}

The notion of connections in philosophy forms the methodological basis for their implementation in criminal law.

The concept of connection (connections) in philosophy is at the same time justifying the emergence of fundamental philosophical approaches: dialectics, metaphysics, hermeneutics, etc.

The concept or conceptus ${ }^{4}$ in philosophy is a definite, generalization of the most characteristic features, features of a scientific object that reflects a real phenomenon.

The concept of "connection" in philosophy meets the criteria of logical scope and content of the concepts of "relation", "correlation"; by a criterion that can be described as a method or form of implementation, it is related to the concepts of "activity", "system", etc.

Yes, it is doctrinally obvious that the concept of "connection" in its ontological characteristics (real justification) are adjacent to the concept of "relation", which is the moment of interaction of phenomena, objects.

Within the general theory of systems, the founders of which are considered to be the founders of A. Bogdanov and L. von Bertalanffy, the system is described in particular as the set of certain elements between which there is a natural connection or interaction ${ }^{5}$.

These philosophical notions of connection underlie the notion of causation as being characterized by temporal (cause preceding in time of consequence) and genetic asymmetry (cause produces consequence, consequence does not cause).

3 Baulin Yu.V., Buromenny M.V., Golina V.V., Grishchuk V.K., Zaichuk O.V., Navrotsky V.O., Naden O.V., Nikitin Yu.V., Onishchenko N.M., Kharitonova Yu.V., Shakun V.I. (2015) Suchasna kryminaljno-pravova systema v Ukrajini: realiji ta perspektyvy [Modern criminal and legal system in Ukraine: realities and prospects]. Kyiv: Vaite, p. 688.

${ }^{4}$ Filosofskiy slovar' (2006) [Philosophical dictionary]. Kyiv: A.S.K., p. 439.

${ }^{5}$ Danilyan O.G., Taranenko V.M. (2012) Filosofiya: uchebnik [Philosophy: Textbook]. Kharkov: Right, p. 229. 
The modern concept of causality implies its modified characteristic as the interaction of phenomena. This somewhat explains the typical concept of cause and effect, as one-sided, asymmetric, within which the cause is generative or distinct. In the modified approach, causality is the connection between objects and phenomena, which is formed by the transfer of action from one object or phenomenon to another (others). However, this view is not about criminal law, but criminology

Generally, within the characteristics of causality and causation, the following provisions are postulated:

1) there is a preliminary assumption that causality is universal, that is, every event has a cause;

2) monotony: the same causes produce the same consequences;

3) temporal asymmetry: the consequence in time always follows for (after) reasons;

4) genetic asymmetry, which, as noted earlier, is somewhat complemented by the possibility of an inverse effect of a consequence (a generating factor) on the cause (in the classical sense, a generating factor).

It should be noted that in addition to the cause, other sub-causal factors (excuse, incentives, circumstances) are of particular importance not to criminal law (solving its problems) but to criminology and psychology; in criminal law, these sub-causal factors are taken into account indirectly, and usually when the stage of criminal procedural implementation of the normative prescriptions of criminal law comes.

The subjective sub-causal factor "motive" is considered as an addition to the characteristic of the behavior of a person considered in criminal law, and in the criminal procedural aspect contributes to a negative result, and in the procedural - substantiates the result.

Within the causality methodology, the following can be stated:

1) the category "connection" is correlated with other categories ("interaction", "system", "structure");

2) it can be argued that causality is the most common form or type of communication that is considered by criminal law;

3) the causal manifestation of the determination must be considered within the framework of the current system of scientific knowledge, modified to take into account relatively new and recent ideas about the functional role and content of causation.

The considerable "specific gravity" of the use of causation in law, in particular in criminal law, is due to the fact that the clarification of causation provides a legal (normative) description or characterization of acts, the commission of which gives rise to certain legal consequences, related to the structure of communication ("cause-and-effect"). 
The latter means that the link has a generalized form: cause-and-effect. But as part of a systematic and meaningful study of causal communication, a number of problems arise, as schematically noted above. The first of these is to establish the limits of causality for law, criminal law. The second is to determine the nature of the effect of the consequence on the cause that can be used in the analysis of causality, which has legal significance.

A separate problem of causality is the delimitation of the so-called "natural" causality from the "social".

"Natural" causality is considered within the limits of natural processes (physical, chemical and similar in nature); "Social" causality is related to the field of social sciences, including with a right, a criminal law. The peculiarity of "social" causality, in particular, lies in the specific mechanism of causing, causing significant and harmful (formally prohibited, punished) consequences.

Methodologically, it is also important to determine the criteria for establishing the true cause of a particular phenomenon and consequence.

In terms of the formal-logical interpretation of causal communication, the formal-logical approach is well-developed and widespread in science.

In particular, this conclusion is based on the existence of such a component of logical science as the logic of causality.

The prerequisites for the emergence of logic of causality are the notion of cause, effect, and causation as a one-sided relationship within which the decisive role is played (exercised) by the cause.

It should be noted that the logic of causality is considered as a special part of philosophical science and a component of logic.

The problem of causality logic is usually considered at the "intersection" of philosophical and logical approaches to understanding causality.

These approaches were implemented within the scientific developments of the famous English scientists F. Bacon and J.S. Mill. In particular, they are known for their ideas in terms of logical interpretation of the concepts of "cause", "causal basis" through the concept of conditions (conditions), which were considered (collectively) as a logical basis for interpretation, prediction of occurrence and logical justification of the result.

The scientific approach developed by these scientists is applied both within the limits of modern formal and logical approaches of understanding of causality, and for solving problems of law and criminal in particular. The purpose of the Bacon-Mill method: the logical demonstration of whether one can consider the previous phenomenon to be the cause of the following ${ }^{6}$.

\footnotetext{
p. 347.

${ }^{6}$ Konversky A.E. (2016) Loghika: pidruchnyk [Logic: a textbook]. Kyiv: Kyiv University,
} 
In this connection, it is worth paying attention to the application of logicalphilosophical approach. J.S. Mill, representatives of the German classical school of law in the development of the theory of causality conditio sine qua non.

A logical interpretation of causality as an objectively existing dependence of phenomena is possible because, in the opinion of specialists in the field, this dependence is characterized by logical content or can be analyzed by logic. As noted, within the logic of causality for causation and causation, the following statements are true:

1) nothing is cause of oneself;

2) if one event is the cause of the second, then the second is not the cause of the first;

3) the same event cannot be both the reason for the presence of an event and the reason for its absence.

Implementation to these prerequisites is concentrated in the causal implication $(A \rightarrow B)$.

In addition, causal logic, as noted in scientific doctrine, is constructed in such a way that the full and incomplete causes were investigated (established).

The combination of these provisions of the logic of causality (causal logic) with the idea of a sufficient basis for the onset of a certain result, which can take a logical form (statement, judgment) has a constructive, that is, necessary to solve the problems of a particular system of scientific knowledge, character.

It should be noted that in formal logic to characterize the dynamics of causal influence is applied not the concept or terminology of philosophical ontology (that is, causation, conditioning), but its special-logical interpretation: "implication".

Formal logic, being applied to solve specific scientific problems, in particular criminal law problems, becomes the logic of scientific research, in particular, the research of causation in criminal law.

Of particular importance in the logical interpretation of causation is the notion of a complete and incomplete cause.

The full reason, as the set of necessary and sufficient conditions for a certain logical result and the notion of an incomplete cause, are of somewhat controversial (ambiguous) importance for use in criminal law evaluation.

Analysis of causal, criminal and legal manifestations (causal relationship as a sign of the objective side; causal connection of the crime and its serious consequences, etc.) allows to make a conclusion regarding the emergence of the problem of the relationship of concepts "full reason", "incomplete reason" with the important, from the author's point of view, the notion of "reason enough". 
The application of a logical idea and the notion of a full cause in criminal law complicates the requirements for a lawyer (qualified, competent lawyer) to find out; in particular, the characteristics of an act that has a criminal law value and causes a criminal offense, harm.

The notion of incomplete cause (taking into account only the necessary conditions of a conceivable logical result) raises the problem of the degree of completeness or incompleteness of the cause in its criminal law interpretation.

Therefore, from the author's point of view, dominant in criminal law is the notion that there is sufficient cause for a criminal offense to occur.

This reason must be such that it can be taken into account criminal law interpretations and assessments.

In regard to the resolution of criminal issues, it is advisable to consider formed on the basis of theoretical generalizations and practical legal activity of the concept of "sufficient cause", which is established in the course of criminal law assessment.

The notion of a full cause makes it possible to identify issues sufficient, which can be considered in the criminal law interpretations of the cause.

Schematically: $P \rightarrow Q$, where $P$ is the set of necessary and sufficient conditions and $Q$ is the result.

With incomplete reason, only the necessary conditions of the result are available, but there are no sufficient ones.

A separate part, within the logical interpretation of causality, form, in terms of the author, the prerequisites for the logic of causality.

The prerequisites for the logic of causality can, from the author's point of view, be constructed in the following sequence:

1) logical operations;

2) terms (logical terminology);

3) Logical and technical means: symbols, logical "icons" used for the logisation of specific scientific operations, processes.

The prerequisite for causal logic and logical interpretation of the causal link under the conditional name "logical operation" is a set of operations accepted in formal logic, reflecting typical ways of thinking of man. These include: implication, conjunction, and disjunction.

Implication (logical operation "implication") can be considered as a logical form of causing (causing) or conditioning the result, regardless of ontological or epistemological approaches to understanding causality; schematic: " $a \rightarrow b$ ", where $a$, what follows the assertion (conclusion, result) $b$.

However, it should be noted that "real" causation cannot always be consistently described by "implication"7 . Example, logical statement: "If the

7 Toftul M.G. (2012) Loghika: slovnyk-dovidnyk [Logic: dictionary-directory]. Kyiv: Academy, p. 118. 
roof is wet, then the rain has passed". The real reason for the "wet" roof is rain; however, the logical cause of the event is the "wet" roof, from which it follows that the rain has passed. That is, "real" and "logical" causality are correlate as a "mirror" inversion.

The ratio of "mirror" inverse dependence (or "mirror" position of the object) is referred to as "inversion".

In connection with the formal and logical study of causation in criminal investigations of causation issues, the definition of is given. J.S. Mill views reason as a set of necessary and sufficient conditions (combined by the concept of "equivalence").

View of J.S. Mill the conditions was supported by K. Birkmeyer; $\mathrm{K}$. Binding believed that the reason arises when positive conditions prevail over negative ones ${ }^{8}$.

\section{Some aspects of the mapping of causal link in the criminal law of the continental and Anglo-Saxon countries}

According to the author, the legal mapping of cause and effect causality is based on the assertion that if the perpetrator implies the development of events then he is criminally responsible?

It should be noted that the main criterion in the comparative-normative study of causality is not the belonging of the law to a specific legal family, but the degree of regulatory explanation of causality in the laws of countries. Accordingly, a certain sequence of comparison is determined based on the specified criterion.

It should also be noted that the degree of regulatory explanation of causality in foreign criminal justice systems and in Ukraine has certain features that characterize causality in the complex of legal justification of a person's criminal liability.

The mapping of causality in the Common Criminal Code, attests to the special role of causation in the justification of criminal liability (the Criminal Code of Georgia, the United States (Model Code), San Marino, etc.).

It should be noted that criminal law and legislation in most countries (both continental and Anglo-Saxon legal systems) do not provide for a causal link (given the importance of this procedure - regulatory regulation).

As a rule, when characterizing a crime in the initial sections ("Books"), the punitive consequence of the crime is emphasized or the subject's guilt is emphasized for committing an act provided for by the criminal law of the

\footnotetext{
${ }^{8}$ Shargorodsky M.D. (2003) Izbrannye raboty po ugolovnomu pravu [Selected criminal law works]. St. Petersburg: Law Center Press, p. 434.

${ }^{9}$ Leyland P. (1996) Kryminaljne pravo [Criminal law]. Kyiv: Foundations, p. 41.
} 
countries; a consequence of the foregoing is that causation is not regarded as a material basis for criminal (criminal) liability; the classic version of the material cause in this case involves the scheme of the form "standardization of crime (with emphasis on its harm) - standardization of causation in a separate article of the General Part (Code, Books) - causation as a mandatory enforceable element and a condition of criminal liability".

It is also possible to draw a preliminary conclusion, based on the analysis of foreign criminal law, that causality (causation) is considered as the moment of legal evaluation of actions.

In particular, for example, the Criminal Code of the Republic of Poland (ed. of 01/01/2016) contains a requirement to law enforcement agencies that the court takes into account when assessing the degree of harmfulness of an act:

1) the type and nature of the infringed good;

2) the amount of the damage caused ${ }^{10}$;

3) the amount of damage that could have been caused;

4) the manner and circumstances of the act.

From the above we can conclude that the crime is considered as an objectively harmful act; items 2,3 , which form the content of the requirement to evaluate the act of interpretation, can be considered as the presence in the Polish criminal (punitive) law of the following types of cause and effect:

a) communication of the type of "action-harm ("real" consequence)";

b) communication of the type of "action-possible harm" or, interpretatively, the threat of harm.

Analysis of the criminal law of foreign countries on normalization of causality (in particular, causation) leads to the general conclusion about different algorithms, ways of its display.

In particular, there is a clear way in which causality in relation to relevancy (statutory characteristics, circumstances) is displayed in the form of regulation for law enforcement agencies; there is a way in which causation is revealed as a moment of criminal law of evaluation of an act (indication of harm, substantial harm, the possibility of harming the object of the attack).

The main goal of various ways of normalizing causal communication is to gain an understanding of the complex of differentiating punished and unpunished behavior of characteristics.

A separate way of normative display of causality is to create conditions for its interpretation within the system of criminal law.

This method, from the author's point of view, is used in the Criminal Code of Ukraine and most CIS countries. At the heart of the method is the idea of

${ }^{10}$ Menchinsky V.L. (ed.) (2016) Kryminaljnyj kodeks Respubliky Poljshha [The Criminal Code of the Republic of Poland]. Kyiv: OVK, p. 47. 
the necessary (regular) causal connection; consequently, causal connection is doctrinal-normative: the view of connection is viewed, in the view of the author of the study, as a certain doctrinal, axiomatic (does not need to prove that the necessary reason is legally significant).

At the same time, this doctrine of "axiomatic" causality can be regarded as a certain legal principle, the beginning of the assessment of the behavior of the subject, to resolve the issue of his criminal liability.

This principle is constantly "verified" and implemented through the Special Part of the Criminal Codes of the mentioned countries; the introduction of the concept of "material composition of the crime" confirms, from the author's point of view, the above.

In addition, it can be argued that the doctrinal-normative, axiomatic notion of causal connection is a benchmark for use by subjects of law.

In particular, in the Criminal Code of the Republic of Belarus from July 9, 1999 Art. 11 "Crime", is considered an act related to the occurrence of consequences; Art. 24 "Guilt in a crime not connected with the occurrence of consequences" in combination with the totality of material warehouses provided for by the Special Part of the said Code.

Interpretation of Part 2 of Art. 11 on the contrary (since "direct" is a characteristic of a minor act) allow us to emphasize causality (causality) at the theoretical and normative level of "crime" by establishing the legal position that the crime (as opposed to a minor action) causes significant harm.

The combination of the provisions of Art. 11 "Concept of crime" and paragraph 5 of Art. 67 ("grave consequences of a crime") provides for consideration of a connection (which is considered outside the composition of the crime) of the form of "crime-grave consequences".

Section II of the current Criminal Code of Ukraine ("Crimes against life and health"), because it contains varieties of murder (material depots), considers causations as an element of the legal constructs of crimes (Articles 115-119); other legal constructs of crimes related to life imprisonment contain specific or missing links (Article 129 "Threat of murder").

Section VI of the current Criminal Code of Ukraine ("Crimes against property"), in so far as it contains varieties of "selfish" crimes (material warehouses), contains causal links, and provides them within the limits of certain articles (Articles 185, 186, 189, 190 and some others).

The analysis of Section VIII ("Environmental Crimes") has the peculiarity (which is characteristic of the codes of individual foreign countries), which defines a specific kind of causal link: "acts-of-danger to objects protected by criminal law".

In the criminal law of other countries apply the concept of "threat", "the amount of harm that could have been caused" and others. 
Accordingly, for example, the legislation of the Republic of Poland interprets causation by focusing on "the amount of harm that could have been caused"; in the legislation of the Republic of Georgia - the action constitutes a "specific danger" in terms of the consequences.

In other sections of the Criminal Code of Ukraine of 05.04.2001, it is possible to distinguish certain legal constructs of actions containing as an element a causal link.

In particular, in this connection it is possible to distinguish Art. 286 of the Criminal Code of Ukraine (Section IX, "Crimes against Public Safety"), Art. 312 of the Criminal Code of Ukraine (Section XIII "Crimes in the Circulation of Narcotic Drugs, Psychotropic Substances, Their Analogues or Precursors, and Other Crimes against Public Health") and others.

Generalization of the peculiarities of normative fixation of causality in the criminal legislation of foreign countries is problematic to this day.

A separate "block" of comparative legal research related to clarification of theoretical issues and legislative reflection of the provisions of the theory of criminal law is the problem of interpretation and legislative consolidation of the activities of accomplices in parts of the criminal legislation of countries.

The analysis of this question leads to the general conclusion that the problem is solved.

However, problematic issues arise within the theoretical and legislative characteristics of the individual elements of complicity.

In particular, there is a distinction between incitement and provocation to commit crimes; determining the time of complicity and some other issues of criminal value.

It should be noted that the European legal tradition provides for detailed regulation of these issues.

At the same time, this regulation does not completely resolve the issue of delimitation of "role" complicity from group, as well as complicity from involvement, etc.

A separate problem related to the reflection of criminal phenomena in criminal law is the display (in some cases) of the so-called "adjudication", which (or the consideration of which) influences the criminal law evaluation of the action.

Prejudice as a criminal phenomenon, expressed in the concept of "pretrial", is envisaged in the legislation and law of some countries of the continental legal system.

Pre-eminence or re-assessment may be considered as a condition of:

1) criminal law evaluation of actions;

2) as a factor that gives rise to or is a condition for the occurrence of certain legal consequences against the person who committed the criminal offenses. 
In particular, it is a criminal law of the Republic of Belarus and some other countries.

It should be noted that the criminal law of some countries contains concepts that certain state institutions (in particular, such as legal commissions) propose to amend or abolish. These include causality-related notions, subcontracting, and more.

The study can be summarized in advance:

1) in both continental and Anglo-Saxon legal systems and the criminal law of the countries represented, historically formed causality theories have been applied; the peculiarity is a concrete situational modification of the approaches of the theories regarding the understanding and establishment of legally significant causal connection;

2) causation is generally considered, in the theory of criminal law, as a substantiating moment concerning the criminal liability of a person;

3) the causal link in the Anglo-Saxon legal system is "tied" to a courtspecific situation;

4) the effectiveness of causation as a condition of a person's liability depends on the normative fixing of its basic characteristics (defined doctrinally) in the General part of a criminal act ("Code", "Statute", etc.);

5) causality in theoretical and normative sense is a separate and not completely resolved problem if viewed through the methodology of comparing different types of criminal law and legislation;

6) causality (within the comparative approach) has its manifestations in such "loci" of the current legislation of foreign countries and Ukraine:

a) complicity in the crime;

b) preliminary assessment (if any);

c) crimes related to harming the victim.

In the Criminal Code of the Republic of Azerbaijan dated January 30, $1999^{11}$, Article 14 "The concept of a crime" contains part 14.2, which provides for the formulation of a minor act (also, which did not cause harm to the individual, society or state); Section VIII ("Crimes against the Person"), crimes related to harm to public relations, etc.

The following legal components of the Criminal Code of Ukraine, dated 05.04.2001, testify to the grounds for the interpretation of the causal link having a criminal legal value:

1) Art. 2 (the basis of criminal liability);

2) Art. 11 ("The concept of crime");

${ }^{11}$ Ragimov I.M. (ed.) (2001) Ugolovnyy kodeks Azerbaydzhanskoy respubliki [Criminal Code of the Republic of Azerbaijan], p. 325. Retrieved from: http://base.spinform.ru/ show_doc.fwx?rgn=2670 (accessed 11 October 2019). 
3) a combination of Art. 11 and item 5 of Art. 67;

4) Section II (Crimes against the life and health of the individual) in part;

5) Section VI ("Crimes against property") in part;

6) Section VIII ("Environmental Crimes");

7) other sections within which there are separate crimes containing causation.

With regard to Article 2 ("Ground of criminal responsibility"), in this case it is necessary to pay attention to the part of the wording of the first article: "The basis of criminal responsibility is the commission of a person of socially dangerous act...".

Obviously, a legal interpretation of the term "socially dangerous act" is needed; by analogy with the approach adopted in the Polish criminal law, in particular, attention should be paid to the harmfulness of the act (the properties of causing harm).

Accordingly, there is an initial opportunity to interpret a legally significant causal link.

Interpretation of Part 2 of Art. 11 and the provisions of the relevant articles of other criminal laws (criminal codes) lead to the conclusion the existence of acts that, although reminiscent of crime, are not such.

Combining the provisions of these articles with an indication of an increased degree of harmful acts constitutes a causal combination of these acts with particularly harmful consequences.

As already noted, Section II of the current Criminal Code of Ukraine ("Crimes against life and health") provides for causation as elements of the legal structures of crime (Articles 115-119); other legal constructs of crimes related to life imprisonment contain specific links or are not linked (Article 129 "Threat of Murder").

As already mentioned, section VI of the current Criminal Code of Ukraine ("Crimes against property") contains acts containing a causal link.

Similarly, the analysis of Section VIII ("Environmental Crimes") has the peculiarity (which is characteristic of the codes of individual foreign countries) that defines a specific kind of causal link: "acts-of-danger to objects protected by criminal law". The return to previous argumentation is driven by the importance of the issues analyzed in the study.

In the criminal law of other countries apply the concept of "threat", "the amount of harm that could have been caused" and others.

The laws of the "Visegrad Four" countries explain the cause-and-effect relationship with a focus on harm.

An analysis of the criminal law of both continental and Anglo-Saxon legal systems leads to the conclusion that causality (causal links) can be considered:

1) within the characteristics of the "complicity" institute; 
2) if there are cases or manifestations of a case-law and its influence on the resolution of the question of criminal liability of a person in the criminal justice systems of different foreign countries;

3) within the characteristics of the legal structures of individual crimes.

As already mentioned, within the Criminal Code of the Kingdom of Spain (adopted on 24/11/1995) $)^{12}$, articles characterizing intentional joint participation in the commission of a crime are published in the various "Books" of the above Code.

Article 17 of the said Code contains provisions on the agreement of two or more persons about the commission of a crime and its commission; Article 18 identifies incitement and provocation to commit a crime; Article 29 defines the time of complicity (causal temporality) at the same time or at the time before the crime.

Article 141 of the Criminal Code of the Kingdom of Spain defines the concepts of "incitement", "conspiracy", "proposal" (the term characterizing causation, connection conditioning).

Section 19 of Chapter 1 of the Criminal Code of Spain contains Art. 404-405, who are punished for abuse of office; Article 407, 408 of which is punishable by non-compliance with criminal prosecution obligations.

The following examples show, from the point of view of the author of the study, the existence of a correlation (causal correlation) between a person's competence and actions characterized as abuse.

In the Criminal Code of the Republic of Poland of 06/07/1996, in the General part, provided for Art. 18 which examines options for liability for a crime, depending on the nature of the crime:

1) performing a prohibited act on your own;

2) execution by agreement;

3) the responsibility of one who directed the commission of the criminal act by another person;

4) the responsibility of the person who used the addiction of the person and recommended the crime.

Item 2 can be interpreted as a manifestation of the correlation between the contracting parties; item 3 - correlation of the organizer with other accomplices; item 4 - exploit the situation or intentionally create such conditions when there is no other way than to commit a crime (communication is conditional).

Article 24 of the Criminal Code of the Republic of Poland provides for or defines the content of the behavior of such an accomplice as incitement:

\footnotetext{
${ }^{12}$ Menchinsky V.L. (ed.) (2016) Kryminaljnyj kodeks Korolivstva Ispanija [Criminal Code of the Kingdom of Spain]. Kyiv: OVK, p. 284.
} 
incitement, depending on the situation, can be considered as a cause (causation) or as a condition (then there is a conditional dependence that is causation).

Article 16 of the Criminal Code of the Republic of Belarus dated $09 / 07 / 1999^{13}$, gives a description of complicity and a list of role accomplices, which in many moments coincides with the provisions of Art. 26, 27 of the Criminal Code of Ukraine from 05/04/2001.

At the same time, a striking feature of the said Code is the presence of Art. 8 "Prejudice of a crime committed in the territory of a foreign country".

In particular, it is regulated (stipulated by law) that criminal convictions and other legal consequences of committing a crime in the territory of a foreign state are of criminal legal value for resolving the issue of criminal liability for a crime committed in the territory of the Republic of Belarus.

Section XIV of the Special Part of the Criminal Code of the Republic of Belarus, in particular, contains legal constructs that include as a causal link element; Article 455, 456 contain situations of abuse, excess or inactivity of "power" subjects.

As noted in such cases, there is a correlation between competence and actions that lead to injury, causing harm (as in the Criminal Code of Ukraine).

British criminal law contained the concept of "incitement"; the Law Commission recommended that the existing form of crime be "subjugated" and replaced with a serious crime; that is, in the Anglo-Saxon legal system one can study cause and effect, but it is mediated by judicial generalizations, decisions for each criminal episode.

\section{CONCLUSIONS}

The following conclusions are needed:

1) in both continental and Anglo-Saxon legal systems and the criminal law of the countries represented by them, scientifically sound grounds and preconditions are required for an in-depth understanding of the place and importance of causation in criminal law;

2) causation is considered in the theory of criminal law as a component of a criminal offense;

3) causality in the Anglo-Saxon legal system is established by lawyers taking into account specific criminal situations;

4) causation as a condition of criminal responsibility of a person depends on theoretical and situational interpretations adopted within the framework of criminal law systems of different countries;

${ }^{13}$ Lukashova A.I., Sarkisova E.A. (eds.) (2001) Ugolovnyy kodeks Respubliki Belarus' [Criminal Code of the Republic of Belarus], p. 312. 
5) causality in theoretical and regulatory sense is a separate and fundamental problem of criminal law and the solution of which depends on the perception of scientific approaches of scientists of different countries;

6) causations (within a comparative approach) have common features both within the theory and law of the continental and Anglo-Saxon countries.

In conclusion, it should be noted that theoretical analysis and legislative reflection of complicity are promising in the study of theory and legislative reflection of causation.

In particular, within the framework of the Institute of complicity (Articles 26-31 of the Criminal Code of Ukraine) a typical causal link between the acts of accomplices in the commission of a deliberate crime and a criminal result is recorded; relevant articles of foreign criminal codes are similarly interpreted or interpreted.

\section{SUMMARY}

The article deals with the problematic issues of theory and the legislative display (fixation) of causality, which is of criminal legal value.

Methods of establishment and specific ways of displaying causal link in criminal law are considered.

The methodological bases of causation are analyzed, which should be considered within the basic level of understanding of cause and effect. Formal and logical grounds for understanding and analyzing causation in criminal law are considered.

It is stated that logical ideas about the implication, the full and incomplete basis (cause) are the basis of separate theories of causation in criminal law.

Various ways of reflecting causation and its characteristics in the criminal law of the countries of continental and Anglo-Saxon legal systems are considered.

The definition of legislative "loci" or those legal institutions within which are considered manifestations of causality.

Particular attention is paid to such components of criminal law as "complicity", "prejudice" and others.

At the level of specific crimes (offenses), within the framework of the legislative display of causation, attention should be paid to crimes related to harming victims.

\section{REFERENCES}

1. Tatsiy V.Ya., Pshonka V.P., Borisova V.I., Tutyugina V.I. (eds.) (2013) Kryminaljnyj kodeks Ukrajiny: Naukovo-praktychnyj komentar. 2 t. [Criminal Code of Ukraine: Scientific and Pracrical Commentary, vol. 2]. Kyiv, p. 1040. 
2. Bigvava Z.K. (2002) Ugolovnyy kodeks Respubliki Gruzii [The Criminal Code of Georgia]. St. Petersburg: Law Center Press, p. 409.

3. Baulin Yu.V., Buromenny M.V., Golina V.V., Grishchuk V.K., Zaichuk O.V., Navrotsky V.O., Naden O.V., Nikitin Yu.V., Onishchenko N.M., Kharitonova Yu.V., Shakun V.I. (2015) Sucнаsna kryminaljno-pravova systema v Ukrajini: realiji ta perspektyvy [Modern criminal and legal system in Ukraine: realities and prospects]. Kyiv: Vaite, p. 688.

4. Filosofskiy slovar' (2006) [Philosophical dictionary]. Kyiv: A.S.K., p. 1056.

5. Danilyan O.G., Taranenko V.M. (2012) Filosofiya: uchebnik [Philosophy: Textbook]. Kharkov: Right, p. 229.

6. Konversky A.E. (2016) Loghika: pidruchnyk [Logic: a textbook]. Kyiv: Kyiv University, p. 391.

7. Toftul M.G. (2012) Loghika: slovnyk-dovidnyk [Logic: dictionarydirectory]. Kyiv: Academy, p. 312.

8. Shargorodsky M.D. (2003) Izbrannye raboty po ugolovnomu pravu [Selected criminal law works]. St. Petersburg: Law Center Press, p. 434.

9. Leyland P. (1996) Kryminaljne pravo [Criminal law]. Kyiv: Foundations, p. 207.

10. Menchinsky V.L. (ed.) (2016) Kryminaljnyj kodeks Respubliky Poljshha [The Criminal Code of the Republic of Poland]. Kyiv: OVK, p. 138.

11. Ragimov I.M. (ed.) (2001) Ugolovnyy kodeks Azerbaydzhanskoy respubliki [Criminal Code of the Republic of Azerbaijan], p. 325. Retrieved from: http://base.spinform.ru/show_doc.fwx?rgn=2670 (accessed 11 October 2019).

12. Menchinsky V.L. (ed.) (2016) Kryminaljnyj kodeks Korolivstva Ispanija [Criminal Code of the Kingdom of Spain]. Kyiv: OVK, p. 284.

13. Lukashova A.I., Sarkisova E.A. (eds.) (2001) Ugolovnyy kodeks Respubliki Belarus' [Criminal Code of the Republic of Belarus], p. 312.

\section{Information about the author: Volodymyr Benkivsky, $\mathrm{PhD}$ in Law,}

Chair of Criminal Law and Criminology, Taras Shevchenko National University of Kyiv

10a, Hnata Yuri str., Kyiv, 03148, Ukraine ORCID ID: orcid.org/0000-0003-4830-8322 